\title{
THE EFFECT OF SILAGE FEEDING ON THE PROPERTIES OF RAS CHEESE
}

Nassib, T. A. *; Y.I. Abdel-Kader ${ }^{* *}$; M.S. Gomma* and Reham K. ElMenawy $^{* *}$

"Fac. of Agric., Dairy Dept., Mansoura Univ.

${ }^{*}$ Dokki. Cairo. Animal Production Res. Institute (APRI)

\section{ABSTRACT}

Two types of milk, namely milk from cow's fed on straw, hay and concentrate (control) and silage milk (from cows fed on silage) were used during this study. Silage milk was divided into three equal parts, The first (control) raw milk without potassium sorbate $(A)$. The second part was heat treated to $63^{\circ} \mathrm{C}$ for $30 \mathrm{~min}$., and cooled to $37^{\circ} \mathrm{C}$ (B). $0.5 \%$ potasium sorbate were added to the third part (c). Normal milk was divided into 2 parts, unheated (D) and heated (E). The above 5 parts were individually processed into Ras cheese. Samples of green cheese were chemically, microbiologically and sensory evaluated throughout the ripening period, extended for 6 months. Results showed that feeding cow's on silage raised the yield of Ras cheese from $9.23 \%$ to $11.65 \%$, also silage heat treated milk resulted in higher yield than raw silage milk. The addition of $0.5 \%$ potasium sorbate decreased the acidity, SN and N.P.N of the matured cheese. Clostridia and Spore forming bacteria were higher in silage milk cheese, as compared with control milk. The addition of $0.5 \%$ potasium sorbate sharply decreased T.C, LAB, coliform, clostridia, spore forming and yeasts and moulds. Silage milk Ras cheese gained the highest scoring point, especially, raw milk cheese, the lowest was for potasium sorbate treatment.

Keywords: Ras cheese, Silage, Clostridium, Potassium sorbate.

\section{INTRODUCTION}

Ras cheese is the most popular hard cheese in Egypt because of its sharp and peppery flavour (El-Shikh. M., et al., 1994). It is known as Cephalotyre cheese in Greece and most of Mediterranean countries (Hofi, et al., 1970). The name Cephalotyre means in Greece language "head" and so the Greece name is translated into Arabic language into Ras Cheese. In Egypt Ras Cheese is processed from cow's milk, sometimes 15\% buffalo's milk as a maximum are added to the cow's milk for cheese making. In Egypt feeding system of milking cow's and buffaloes depends mainly on multicut clover during Winter and Spring, while straw, hay and concentrates were fed during Summer season.

Because of malnutrition of animals during Summer season, the production of milk is very low in quantity and quality. Silage is anaerobic fermented feed from green fodder crops resulting during the storage and fermentation under anaerobic condition, It is well known in the developed countries. It is made from green fodder crops containing carbohydrates like corn silage, and molasses were added to poor carbohydrates containing crops like clover. Feeding on silage in European countries creates the problem of late-blowing defect to hard and semi-hard cheese caused by anaerobic spore-forming bacteria such as species of Clostridium. Now the use of silage in cow's and buffaloe's feeding is increased in Egypt, especially, 
Nassib, T. A. et al.

in Summer season, because of its low price and its effects on increasing of the yield of milk:

So the aim of this investigation is to elucidate the following topics: The effect of silage feeding on the quality of Ras cheese, the effect of heat treatment on the presence of anaerobic bacteria group (clostridium) and the addition of potassium sorbate to improve the physicochemical and microbiological properties of Ras cheese.

\section{MATERIALS AND METHODS}

Fresh evening and morning cow's milk used during this study was obtained from El-Serw Animal Production Research Station, having T.S (10.9-12.50\%), Fat (3-3.5\%) and total protein (2.9-3.4\%). Two types of milk were used for Ras cheese making:

a) milk from cow's fed on silage for 15 days, b) milk from cow's fed on traditional feed (rice straw, hay and concentrates).

Local Commercials liquid rennet obtained from local market, was used to coagulate the cheese milk in 45 minutes. Yoghurt starter culture containing Streptococcus thermophilus: Lactobacillus delbrueckii spp. bulgrisus (1:1) obtained from Hansan Company/Denmark. Dry Commercial food grade sodium shloride was obtained from El-Naser Salines Company, Alexandria was used during this investigation. Analytical grade calcium chloride being obtained from El-Gomhoria, Chemical Company, Egypt, were used. potasium sorbate food grade type, was brought from El-Gomhoria Chemical Company, Cairo. Admixture of bees'wax + paraffin wax and vaslin at a ratio of 1:1:0.25 was prepared for coating the Ras cheese. Waxes and Vaslin were obtained from Chemical Company, Egypt. Cheeses were rubbed by $3 \%$ potassium sorbate solution before waxing. Leucerne silage prepared in El-Serw station for 60 days. Silage made by admixing $80 \%$ multicut clover $+15 \%$ rice straw with $5 \%$ molasses and fermented together. A layer of rice straw followed by a layer of clover then moistened by diluted molasses. The layers are repeated and followed to have $2 \mathrm{~m}$. height heap. The heap is well preseed to have anaerobic media then tightly covered with plastic. A layer of soil $(40 \mathrm{~cm}$.) was placed cheet on the Plastic sheet to expel the air. Silage left 70 days to complete fermentation before cow's fedding. Rase cheese was manufactured followed the method by (Tawab, 1963). 45 and 60 days old samples of clover silage were collected from different depth of the pitch, and thoroughly mixed together, then representatives $10 \mathrm{gm}$ were mixed well in the blender with $100 \mathrm{ml} 2 \%$ sodium citrate, the bottles were left 5 minutes, for $1 \mathrm{ml}$ from the upper layer of the emulation was taken and poured in $9 \mathrm{ml}$ distilled water having the dilution of 1:100. Straw and hay were well chopped, while samples of concentrates was ground and similar to silage. Samples were prepared for micro biological assays. Fresh cheese and cheese samples after $1,2,3,4,5$ and 6 months were taken and analysed chemically, microbiologically and sensory evaluation. Samples were threshed before performing the tests. For microbiological analysis $10 \mathrm{gm}$ of cheese were well threshed and added to $100 \mathrm{ml}$ sterilized of $2 \%$ sodium citrate solution and well mixed $1 \mathrm{ml}$ of this emulsion represented dilution of $1: 10$. Total solid, fat, total 
protein content and soluble protein , tiratable acidity of milk, curd, whey and cheese were estimated as lactic acid \% according to (AOAC, 2000). The $\mathrm{pH}$ values of all sample of milk, curd, whey and cheese were measures using a glass electrode $\mathrm{pH}$ meter type GG710, Germany. The Volhrd's method as described by (Richardson, 1985) was used to determine the salt content of cheese.

The NPN was determined as described by (Ling, 1963). T.V.FA was determined according to (Kosikowiski, 1978). Pannel tests was carried out by 10 person, who evaluated the organoleptic properties of cheese samples. The panelists scored the cheese for flavour (50 point), body and texture (35 point) and color and appearance (15 point) as described by (Scott, 1981). Total counts of different milk, whey, curd and cheese samples were enumerated on nutrient a gar medium being prepared according to (Difco, 1971). Enumeration of lactic acid bacteria was done on (MRS) medium being prepared according to (Difco, 1971). MacConkey agar plate count medium was followed to enumerate the coliform group using the method described in (The Standard Methods for Examination of Milk and dairy products, 1960). Reinforced Clostridium Medium (RCM) as prepared by (Gibbs \& France, 1965) was used for enumerated anaerobic bacteria. The medium has the following composition:

$\begin{array}{ll}\text { Yeast extract } & 3.0 \mathrm{~g} \\ \text { Lab-Lemcopowder } & 10.0 \mathrm{~g} \\ \text { Peptone } & 10.0 \mathrm{~g} \\ \text { Slouble starch } & 1.0 \mathrm{~g} \\ \text { Glucose } & 5.0 \mathrm{~g} \\ \text { Cysteine hydrochloride } & 0.5 \mathrm{~g} \\ \text { Sodium Chloride } & 5.0 \mathrm{~g} \\ \text { Sodium acetate } & 3.0 \mathrm{~g} \\ \text { Agar } & 0.5 \mathrm{~g} \\ \text { Dist. Water } & 1000.0 \mathrm{ml} \\ & \mathrm{pH} 6.8 \pm 0.2 \text { at } 25^{\circ} \mathrm{C}\end{array}$

Nutrient Agar medium was used for enumeration of spores. The tube of dilution $1: 1000$ is heated in water bath to $80^{\circ} \mathrm{C}$ for 10 minutes before inoculation then cooled and poured for plate count enumeration according (Chalmers, 1962). Moulds and Yeasts were counted on Potato Dextrose Agar (PDA) medium according to (Difco, 1971).

\section{RESULTS AND DISCUSSION}

\section{The effect of silage feeding on properties of Ras cheese:}

Table " 1 " shows the enumeration of certain group of microorganisms grown on different media for 45 and 60 days old silage of multicute clover and (straw, hay and concentrates) prepared for feeding.

From table "1" it is clear that silage has higher T.C as compared with the concentrates. It could also be observed that both of lactic acid bacterial numbers and coliforms were lower in the concentrates, and no colonies of clostridia were detected on the RCM. The concentrates were also found completely free of spore formes. On the other hand, colonies of mold and 
Nassib, T. A. et al.

yeast grown on P.D.A are slighty lower $\left(0.12 \times 10^{5}\right)$ c.f.u/g in concentrates, compared with silage samples. Silage feeds, however, contained higher number of total bacterial counts and coliforms, whereas their content of clostridium and spore formers were very low.

The Presence of many colonies of anaerobic bacteria in silage is normal because the environmental anaerobic conditions for the growth of anaerobic bacteria (such as Clostridium) is available.

Table (1): Microbiological analysis of silage, straw, hay, and concentrates No. of Bacteria $\left(\times 10^{5}\right)$ c.f.u $/ \mathrm{g}$.

\begin{tabular}{|c|c|c|c|c|c|c|}
\hline Media & T.C & $\begin{array}{c}\text { Lactic acid } \\
\text { Bacteria }\end{array}$ & $\begin{array}{c}\text { Coliforms } \\
\text { bact. }\end{array}$ & Clostridia & $\begin{array}{c}\text { Spore } \\
\text { forming }\end{array}$ & $\begin{array}{c}\text { Yeast and } \\
\text { moulds }\end{array}$ \\
\hline 45 days silage & 138 & 82 & 10.5 & 0.85 & 0.25 & 0.33 \\
\hline 60 days silage & 130 & 71 & 8.9 & 0.71 & 0.22 & 0.48 \\
\hline $\begin{array}{c}\text { Straw + hay + } \\
\text { concentrates }\end{array}$ & 15 & 0.002 & 4.1 & - & - & 0.12 \\
\hline
\end{tabular}

From Table " 2 " it is clear that the yield of fresh Ras cheese obtained from silage milk is higher (11.65\%) than control milk cheese $(9.23 \%)$. Gukov (1994) found that feeding cow's on silage, increased the yield of cheese and improving their quality. Heating the milk before cheese making raised the yield of the cheese by (11.70 and $9.52 \%)$ for control and silage milk, respectively.

Table (2) :Effect of silage feeding on fresh Ras cheese yield

\begin{tabular}{|c|c|c|c|c|c|}
\hline \multirow{2}{*}{ Treatment } & \multicolumn{2}{|c|}{ Control milk } & \multicolumn{3}{|c|}{ Silage milks } \\
\cline { 2 - 6 } & A & B & C & D & E \\
\hline Yield & $9.23 \%$ & $11.70 \%$ & $11.65 \%$ & $12.67 \%$ & $12.81 \%$ \\
\hline
\end{tabular}

\section{A: Control milk (raw)}

B: Control milk (Heat treated)

C: Raw silage milk

D: Heat treated silage milk

E: Heat treated silage milk $+0.5 \%$ Potassium sorbate

Table ( 3 and 4 ) show the chemical composition of different cheeses as affected by silage feeding throughout 6 months of ripening. For all treatments, as ripening period progressed, T.S, fat, protein and salt contents also increased. This apparent increase is owing to the evaporation of moisture from the cheese surface. This increase might also be due to the salting process during the first month of ripening at room temperature. Hofi, et al. (1970) stated that there is an increase of T.S, fat, protein and salt in Ras cheese during the ripening period, because the moisture content was decreased.

Coating the cheese decreased the losses in moisture content. Similar results are also obtained by Abdou, et al. (1977), who found that cheese coated with paraffin wax blends and plastics supensions resulted in differences rates of moisture loss. our obtained results are higher than those 
obtained by Hagrass, et al. (1984) who found that moisture content were 41.47 and $33.91 \%$ for fresh and 6 months old ras cheese, Respectively.

As ripening period progressed T.S, fat and protein gradually increased. The gradual increase in the fat content of the cheese is due to the progressive loss in moisture occurring during ripening period. These trend was reported by Omer and Buchheim (1983) and Hofi, et al. (1991) . Stated that the decrease of Ras cheese moisture content was sharp during first month, followed by gradual decrease during the rest of ripening period.

Table (3): Effect of ripening on the moisture, acidity, $\mathrm{pH}$, salt and salt/moisture in Ras cheese made from silage milk

\begin{tabular}{|c|c|c|c|c|c|c|c|}
\hline \multicolumn{2}{|c|}{ Treatments } & Ripening & Moisture & Acidity & pH & Salt & $\begin{array}{c}\text { Salt/ } \\
\text { moisture }\end{array}$ \\
\hline \multirow{14}{*}{ 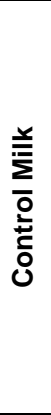 } & \multirow{7}{*}{ A } & 0 & 46.18 & 0.98 & 5.21 & 1.80 & 3.83 \\
\hline & & 1 & 42.09 & 1.22 & 4.91 & 3.29 & 7.81 \\
\hline & & 2 & 40.90 & 1.36 & 4.83 & 3.35 & 8.19 \\
\hline & & 3 & 38.79 & 1.58 & 4.71 & 3.50 & 9.02 \\
\hline & & 4 & 38.09 & 1.94 & 4.62 & 4.05 & 10.63 \\
\hline & & 5 & 37.02 & 1.82 & 4.73 & 4.10 & 11.07 \\
\hline & & 6 & 36.96 & 1.79 & 4.84 & 4.30 & 11.63 \\
\hline & \multirow{7}{*}{ B } & 0 & 45.44 & 0.87 & 5.62 & 1.94 & 4.26 \\
\hline & & 1 & 41.88 & 1.12 & 5.11 & 3.31 & 7.90 \\
\hline & & 2 & 39.99 & 1.24 & 5.01 & 3.82 & 9.55 \\
\hline & & 3 & 37.86 & 1.41 & 4.67 & 3.98 & 10.51 \\
\hline & & 4 & 37.19 & 1.76 & 4.52 & 4.15 & 11.15 \\
\hline & & 5 & 36.93 & 1.64 & 4.62 & 4.33 & 11.72 \\
\hline & & 6 & 35.84 & 1.58 & 4.71 & 4.50 & 12.55 \\
\hline \multirow{21}{*}{ 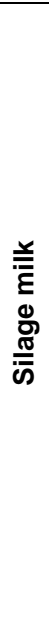 } & \multirow{7}{*}{ C } & 0 & 44.80 & 0.90 & 5.30 & 2.11 & 4.70 \\
\hline & & 1 & 40.96 & 1.31 & 5.15 & 3.41 & 8.32 \\
\hline & & 2 & 38.79 & 1.38 & 5.05 & 3.50 & 9.02 \\
\hline & & 3 & 37.15 & 1.65 & 5.0 & 3.65 & 9.82 \\
\hline & & 4 & 36.85 & 1.83 & 4.90 & 3.91 & 10.61 \\
\hline & & 5 & 35.97 & 1.75 & 4.95 & 4.15 & 11.53 \\
\hline & & 6 & 34.90 & 1.72 & 5.01 & 4.41 & 12.63 \\
\hline & \multirow{7}{*}{ D } & 0 & 43.36 & 0.83 & 5.25 & 2.21 & 5.09 \\
\hline & & 1 & 39.80 & 1.27 & 5.20 & 3.50 & 8.79 \\
\hline & & 2 & 38.50 & 1.33 & 5.14 & 3.80 & 9.87 \\
\hline & & 3 & 36.78 & 1.58 & 5.03 & 3.90 & 10.60 \\
\hline & & 4 & 35.83 & 1.75 & 5.0 & 4.12 & 11.49 \\
\hline & & 5 & 35.12 & 1.65 & 4.89 & 4.30 & 12.24 \\
\hline & & 6 & 33.29 & 1.52 & 4.85 & 4.52 & 13.57 \\
\hline & \multirow{7}{*}{$\mathbf{E}$} & 0 & 44.59 & 0.73 & 5.51 & 2.10 & 4.70 \\
\hline & & 1 & 40.80 & 0.83 & 5.32 & 3.45 & 8.45 \\
\hline & & 2 & 38.66 & 0.96 & 4.91 & 3.72 & 9.57 \\
\hline & & 3 & 37.30 & 1.28 & 4.82 & 3.88 & 10.40 \\
\hline & & 4 & 36.29 & 1.47 & 4.65 & 4.09 & 11.27 \\
\hline & & 5 & 35.92 & 1.42 & 4.73 & 4.20 & 11.69 \\
\hline & & 6 & 35.08 & 1.40 & 4.81 & 4.30 & 12.25 \\
\hline
\end{tabular}

From table "4" It is clear that feeding cow's on silage led to an increase of T.S, fat and protein contents of fresh cheese by 2.54, 5.52 and $4.19 \%$ respectively. By the end of ripening, respective increase were 3.26 , 6.36 and $4.49 \%$ for T.S, fat and protein , respectively for raw milk treatments ( $A$ and C). Pirisi, et al. (2001) found that fed ewes on hay, silage and concentrate increased the fat, T.S contents of the resultant cheese. 
Nassib, T. A. et al.

The heat treatment of milk prior cheese processing led to an increase in T.S. of both treatments by 1.37 and $2.60 \%$ for zero time control and silage milk cheese and 1.77 and 2.77 for 6months ripened cheese, respectively.

Fat and protein content of 6 months ripened cheese ranged between $(36.02-33.16 \%)$ for fat and (31.83-29.81\%) for protein (heat treated milk cheese). Ayad (2004) and Awad (2006) found that values for fat/protein, T.S and Salt of raw milk cheese was slightly lower than those of pasteurized milk cheeses and the acidity was higher for raw milk cheese.

Table (4): Effect of Silage feeding on T.S Fat Fat/T.S Protein Protein /T.S

\begin{tabular}{|c|c|c|c|c|c|c|c|}
\hline \multicolumn{2}{|c|}{ Treatments } & $\begin{array}{l}\text { Ripening period } \\
\text { (month) }\end{array}$ & T.S & Fat & Fat/T.S & Protein & $\begin{array}{l}\text { Protein } \\
\text { /T.S }\end{array}$ \\
\hline \multirow{14}{*}{ 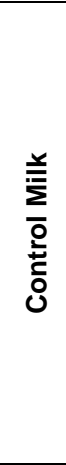 } & \multirow{7}{*}{ A } & 0 & 53.82 & 24.81 & 46.09 & 22.19 & 41.23 \\
\hline & & 1 & 57.91 & 27.99 & 48.33 & 25.33 & 43.74 \\
\hline & & 2 & 59.10 & 29.18 & 49.37 & 26.12 & 44.19 \\
\hline & & 3 & 61.21 & 31.03 & 50.69 & 27.91 & 45.59 \\
\hline & & 4 & 61.91 & 31.92 & 51.55 & 28.62 & 46.22 \\
\hline & & 5 & 62.98 & 32.80 & 52.08 & 29.16 & 46.30 \\
\hline & & 6 & 63.04 & 33.16 & 52.66 & 29.81 & 47.28 \\
\hline & \multirow{7}{*}{ B } & 0 & 54.56 & 25.38 & 46.51 & 22.98 & 42.11 \\
\hline & & 1 & 58.12 & 28.14 & 48.41 & 26.41 & 45.44 \\
\hline & & 2 & 60.01 & 30.28 & 50.45 & 27.35 & 45.57 \\
\hline & & 3 & 62.14 & 31.91 & 51.35 & 28.45 & 45.78 \\
\hline & & 4 & 62.81 & 32.41 & 51.60 & 29.21 & 46.31 \\
\hline & & 5 & 63.07 & 33.41 & 52.97 & 30.01 & 47.58 \\
\hline & & 6 & 64.16 & 34.31 & 53.47 & 30.81 & 48.02 \\
\hline \multirow{21}{*}{ 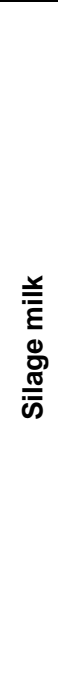 } & \multirow{7}{*}{ C } & 0 & 55.20 & 26.18 & 47.42 & 23.12 & 41.88 \\
\hline & & 1 & 59.04 & 29.21 & 49.47 & 26.17 & 44.32 \\
\hline & & 2 & 61.21 & 31.14 & 50.87 & 28.05 & 45.82 \\
\hline & & 3 & 62.85 & 33.04 & 52.56 & 28.91 & 45.99 \\
\hline & & 4 & 63.15 & 33.91 & 53.69 & 29.17 & 46.19 \\
\hline & & 5 & 64.03 & 34.40 & 53.72 & 30.12 & 47.04 \\
\hline & & 6 & 65.10 & 35.27 & 54.17 & 31.15 & 47.84 \\
\hline & \multirow{7}{*}{ D } & 0 & 66.64 & 26.18 & 45.22 & 24.01 & 42.39 \\
\hline & & 1 & 60.20 & 31.02 & 51.52 & 27.74 & 46.07 \\
\hline & & 2 & 61.50 & 32.39 & 52.09 & 29.20 & 47.31 \\
\hline & & 3 & 63.22 & 33.64 & 53.21 & 29.50 & 47.47 \\
\hline & & 4 & 64.17 & 34.17 & 53.24 & 30.51 & 47.54 \\
\hline & & 5 & 64.88 & 35.27 & 54.36 & 30.95 & 47.70 \\
\hline & & 6 & 66.22 & 36.02 & 54.39 & 31.83 & 48.06 \\
\hline & \multirow{7}{*}{$\mathbf{E}$} & 0 & 55.41 & 25.17 & 54.42 & 23.11 & 41.70 \\
\hline & & 1 & 59.20 & 30.12 & 50.87 & 27.16 & 45.87 \\
\hline & & 2 & 61.14 & 31.21 & 51.04 & 28.16 & 46.05 \\
\hline & & 3 & 62.70 & 32.17 & 51.13 & 28.95 & 46.17 \\
\hline & & 4 & 63.71 & 32.98 & 51.76 & 29.71 & 46.63 \\
\hline & & 5 & 64.08 & 33.91 & 52.90 & 29.95 & 46.73 \\
\hline & & 6 & 64.92 & 34.91 & 53.77 & 30.71 & 47.30 \\
\hline
\end{tabular}

A: Control milk (raw)

B: Control milk (Heat treated)

C: Raw silage milk

D: Heat treated silage milk

E: Heat treated silage milk $+0.5 \%$ Potassium sorbate

Salt content of fresh cheese ranged between (2.21-1.80\%), this salt content was gained during the addition of $3 \%$ salt in the whey. By the second month the salt content is highly increased because of the dry salting. By the 
end of ripening the percentage of salt ranged between (4.52-4.30\%). Ismail (2001) processed Ras cheese from baffaloe's and goat's milk (1:1). The salt content ranged between $(3.188 \%$ and $4.533 \%)$ for fresh and 180 days old cheese. Similarly to fat and protein, fat/protein and protein/T.S increased as ripening period progressed Fat/T.S for ripened cheeses ranged between $(52.60 \%$ and $53.77 \%)$ Respective values for protein/T.S are between (47.88\% and 48.06).

Table "5" show the S.N, S.N/T.N, N.P.N. N.P.N/T.N and T.V.F.A of different treatments. For all treatments $(A, B, C, D$ and $E)$ as ripening period progressed, S.N, S.N/T.N, N.P.N. N.P.N/T.N and T.V.F.A paralley increased. The increase of ripening indices values were higher for raw milk cheese, as compared with heat treated milk cheese (A and C treatment). Hofi (1970), Ayad (2004), Awad (2006) found that ripening indices were higher in raw milk cheese than pasteurized milk cheese during ripening. The Lowest Values were obtained in cheese treated with potassium sorbate treatment $(E)$. Cheese produced from silage milk ( $C$ and $F$ treatment) had higher ripening indices, as compared with control milk ( $\mathrm{A}$ and $\mathrm{B}$ treatment). Pirisi, et al., (2001) fed two groups of ewes on two rations, The first included hay, silage and concentrate, The second fed on Italian ryegrass. Fat content of cheese was higher in the first group while microbiological characteristics and protein were less. By the heat treatment, values of S.N, S.N/T.N, N.P.N. N.P.N/T.N and T.V.F.A were detected in sulilage raw milk cheese were 0.42, 8.60, $0.085,1.74 \%$ and $33.5 \%$ after 6 months. Respective values for traditional feeding cheese were $0.37,7.92,0.07,1.49 \%$ and $32.40 \%$ in the same order. The addition of $0.5 \%$ potassium sorbate to cheese milk may affect the starter activity, decreased the acidity and the ripening indices. Sakr (1998) found that the addition of preservatives to the curd of pyramid cheese highly decreased the values of S.N and N.P.N in the final cheese. This might be due to the effect of preservatives in decreasing and inhibiting the activity of starter bacteria, S.N./T.N of fresh Ras cheese were 4.32, 2.72, 5.24, $4.52 \%$ and $3.86 \%$ for $A, B, C, D$ and $E$, respectively. T.V.FA gradually increased to reach $32.40,31.00,33.50 \%$ and $29.70 \%$ for $A, B, C, D$ and $E$ treatments.

Table "6" showed the count of different microbial groups of Ras cheese during storage period being extended for 6 months at $16 \pm 20^{\circ} \mathrm{C}$. For all treatments, the T.C and LAB decreased during ripening period. Although all treatments were inoculated by $1 \%$ yoghurt starter, number of T.C and LAB were different. Generally raw milk, had higher numbers as compared with heat treated milk, and silage milk contained higher numbers than control milk.

As ripening progressed, number of T.C and LAB gradually decreased to reach the lowest number by the 6 months. The addition of $0.5 \%$ potassium sorbate greatly reduced the total count and also decreased the lactic acid, bacteria count, but in less extent the number of anaerobic and aerobic colonies and strongly destroyed moulds and yeast. The presence of yeasts and moulds at the third month is owing to the recontamination, which happened during ripening, Potassium sorbate also had sharp effect on coliform bacteria. Rehmn (1961) and Luck (1972) summarized the effect of potassium sorbate on different microorganisms and gave the fit al doses for destroyed the different microbial groups. 
Nassib, T. A. et al.

Table (5): Effect of ripening on the nitrogenus contents of Ras cheese made from silage milk

\begin{tabular}{|c|c|c|c|c|c|c|c|c|c|}
\hline \multicolumn{2}{|c|}{ Treatments } & $\begin{array}{c}\text { Ripening } \\
\text { period }\end{array}$ & T.P & T.N & S.N & S.N/T.N & N.P.N & N.P.N/T.N & T.V.F.A \\
\hline \multirow{14}{*}{ 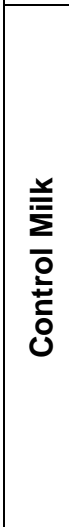 } & \multirow{7}{*}{ A } & 0 & 22.19 & 3.47 & 0.15 & 4.32 & 0.012 & 0.34 & 10.20 \\
\hline & & 1 & 25.33 & 3.97 & 0.21 & 5.28 & 0.021 & 0.52 & 16.80 \\
\hline & & 2 & 26.12 & 4.09 & 0.24 & 5.86 & 0.030 & 0.73 & 21.90 \\
\hline & & 3 & 27.91 & 4.37 & 0.28 & 6.40 & 0.039 & 0.89 & 25.80 \\
\hline & & 4 & 28.16 & 4.41 & 0.32 & 7.25 & 0.042 & 0.95 & 27.00 \\
\hline & & 5 & 29.16 & 4.57 & 0.34 & 7.43 & 0.055 & 1.20 & 30.80 \\
\hline & & 6 & 29.81 & 4.67 & 0.37 & 7.92 & 0.070 & 1.49 & 32.40 \\
\hline & \multirow{7}{*}{ B } & 0 & 22.98 & 3.60 & 0.10 & 2.77 & 0.010 & 0.27 & 9.80 \\
\hline & & 1 & 26.41 & 4.13 & 0.15 & 3.63 & 0.018 & 0.43 & 15.20 \\
\hline & & 2 & 27.35 & 4.28 & 0.20 & 4.67 & 0.020 & 0.46 & 20.30 \\
\hline & & 3 & 28.45 & 4.45 & 0.23 & 5.16 & 0.025 & 0.56 & 24.60 \\
\hline & & 4 & 29.21 & 4.57 & 0.28 & 6.12 & 0.030 & 0.65 & 26.00 \\
\hline & & 5 & 30.01 & 4.70 & 0.31 & 6.59 & 0.038 & 0.80 & 29.00 \\
\hline & & 6 & 30.81 & 4.82 & 0.33 & 6.84 & 0.050 & 1.03 & 31.00 \\
\hline \multirow{21}{*}{ 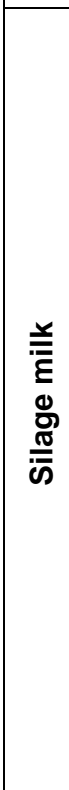 } & \multirow{7}{*}{ C } & 0 & 23.12 & 3.62 & 0.19 & 5.24 & 0.020 & 0.55 & 10.67 \\
\hline & & 1 & 26.17 & 4.10 & 0.24 & 5.85 & 0.029 & 0.70 & 17.50 \\
\hline & & 2 & 28.05 & 4.39 & 0.28 & 6.37 & 0.035 & 0.79 & 22.00 \\
\hline & & 3 & 28.91 & 4.53 & 0.31 & 6.84 & 0.040 & 0.88 & 26.00 \\
\hline & & 4 & 29.17 & 4.57 & 0.35 & 7.65 & 0.053 & 1.15 & 27.50 \\
\hline & & 5 & 30.12 & 4.72 & 0.37 & 8.26 & 0.066 & 1.39 & 31.90 \\
\hline & & 6 & 31.15 & 4.88 & 0.42 & 8.60 & 0.085 & 1.74 & 33.50 \\
\hline & \multirow{7}{*}{ D } & 0 & 24.01 & 3.76 & 0.17 & 4.52 & 0.015 & 0.39 & 8.60 \\
\hline & & 1 & 27.74 & 4.34 & 0.22 & 5.06 & 0.025 & 0.57 & 15.20 \\
\hline & & 2 & 29.20 & 4.57 & 0.26 & 5.68 & 0.033 & 0.72 & 19.30 \\
\hline & & 3 & 29.50 & 4.62 & 0.29 & 6.06 & 0.038 & 0.82 & 23.10 \\
\hline & & 4 & 30.51 & 4.85 & 0.32 & 6.69 & 0.044 & 0.90 & 27.00 \\
\hline & & 5 & 30.95 & 4.98 & 0.35 & 7.21 & 0.050 & 1.00 & 29.50 \\
\hline & & 6 & 31.83 & 5.06 & 0.39 & 7.83 & 0.075 & 1.48 & 30.00 \\
\hline & \multirow{7}{*}{$\mathbf{E}$} & 0 & 23.11 & 3.62 & 0.14 & 3.86 & 0.010 & 0.27 & 8.40 \\
\hline & & 1 & 27.16 & 4.25 & 0.20 & 4.70 & 0.015 & 0.35 & 14.80 \\
\hline & & 2 & 28.16 & 4.41 & 0.22 & 4.98 & 0.020 & 0.45 & 18.80 \\
\hline & & 3 & 28.95 & 4.53 & 0.25 & 5.51 & 0.025 & 0.55 & 22.60 \\
\hline & & 4 & 29.71 & 4.65 & 0.28 & 6.02 & 0.029 & 0.62 & 26.40 \\
\hline & & 5 & 29.95 & 4.69 & 0.30 & 6.39 & 0.033 & 0.70 & 28.30 \\
\hline & & 6 & 30.71 & 4.81 & 0.31 & 6.44 & 0.040 & 0.083 & 29.70 \\
\hline \multicolumn{3}{|c|}{ rol milk (raw) } & & & & $\begin{array}{l}\text { ated) } \\
\text { ilk }\end{array}$ & & & \\
\hline
\end{tabular}


Table (6): Effect of silage feeding, heat treatment and potassium sorbate addition on the microbial counts of Ras cheese during ripening

(No. of Bacteria $\left(\times 10^{5}\right)$ c.f.u/g)

\begin{tabular}{|c|c|c|c|c|c|c|c|c|}
\hline \multicolumn{2}{|c|}{ Treatments } & $\begin{array}{l}\text { Ripening } \\
\text { period } \\
\text { (month) }\end{array}$ & T.C & LAB & Coliform & Clostridia & $\begin{array}{l}\text { Spore } \\
\text { forming }\end{array}$ & $\begin{array}{l}\text { Yeasts } \\
\text { and } \\
\text { moulds }\end{array}$ \\
\hline \multirow{14}{*}{ 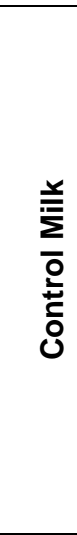 } & \multirow{7}{*}{ A } & 0 & 30 & 0.15 & 0.20 & 0.21 & 0.02 & 0.05 \\
\hline & & 1 & 25 & 0.11 & 0.17 & 0.32 & 0.05 & 0.05 \\
\hline & & 2 & 22 & 0.09 & 0.14 & 0.33 & 0.06 & 0.03 \\
\hline & & 3 & 20 & 0.07 & 0.11 & 0.35 & 0.08 & 0.02 \\
\hline & & 4 & 17 & 0.05 & 0.09 & 0.22 & 0.11 & 0.01 \\
\hline & & 5 & 12 & 0.03 & 0.07 & 0.18 & 0.14 & 0.01 \\
\hline & & 6 & 20 & 0.03 & 0.05 & 0.15 & 0.16 & 0.01 \\
\hline & \multirow{7}{*}{ B } & 0 & 28 & 0.10 & - & 0.01 & - & 0.05 \\
\hline & & 1 & 25 & 0.08 & - & 0.02 & - & 0.04 \\
\hline & & 2 & 20 & 0.05 & - & 0.02 & - & 0.04 \\
\hline & & 3 & 17 & 0.04 & - & 0.03 & - & 0.03 \\
\hline & & 4 & 12 & 0.03 & 0.02 & 0.01 & 0.01 & 0.02 \\
\hline & & 5 & 10 & 0.03 & 0.03 & 0.01 & 0.01 & 0.02 \\
\hline & & 6 & 9 & 0.03 & 0.04 & 0.01 & - & 0.01 \\
\hline \multirow{21}{*}{ 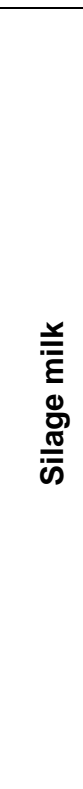 } & \multirow{7}{*}{ C } & 0 & 33 & 0.18 & 0.17 & 0.30 & 0.03 & 0.07 \\
\hline & & 1 & 30 & 0.16 & 0.15 & 0.28 & 0.03 & 0.05 \\
\hline & & 2 & 25 & 0.13 & 0.13 & 0.24 & 0.02 & 0.05 \\
\hline & & 3 & 22 & 0.11 & 0.10 & 0.38 & 0.02 & 0.03 \\
\hline & & 4 & 18 & 0.09 & 0.07 & 0.44 & 0.05 & 0.02 \\
\hline & & 5 & 15 & 0.05 & 0.05 & 0.51 & 0.07 & 0.02 \\
\hline & & 6 & 13 & 0.04 & 0.05 & 0.62 & 0.08 & 0.01 \\
\hline & \multirow{7}{*}{ D } & 0 & 30 & 0.15 & 0.02 & 0.18 & 0.03 & 0.03 \\
\hline & & 1 & 25 & 0.12 & 0.02 & 0.15 & 0.03 & 0.03 \\
\hline & & 2 & 23 & 0.09 & 0.03 & 0.11 & 0.02 & 0.03 \\
\hline & & 3 & 20 & 0.07 & 0.04 & 0.09 & 0.02 & 0.02 \\
\hline & & 4 & 17 & 0.05 & 0.04 & 0.22 & 0.03 & 0.02 \\
\hline & & 5 & 14 & 0.05 & 0.04 & 0.25 & 0.04 & 0.01 \\
\hline & & 6 & 10 & 0.04 & 0.06 & 0.32 & 0.015 & 0.01 \\
\hline & \multirow{7}{*}{$E$} & 0 & 2 & 0.9 & - & 0.01 & - & - \\
\hline & & 1 & 10 & 0.7 & - & 0.03 & - & - \\
\hline & & 2 & 10 & 0.6 & - & 0.04 & - & 0.01 \\
\hline & & 3 & 8 & 0.5 & 0.01 & 0.01 & 0.01 & 0.04 \\
\hline & & 4 & 5 & 0.4 & 0.01 & 0.01 & 0.01 & 0.06 \\
\hline & & 5 & 4 & 0.3 & 0.01 & 0.02 & 0.01 & 0.07 \\
\hline & & 6 & 4 & 0.3 & 0.01 & 0.02 & 0.01 & 0.08 \\
\hline
\end{tabular}

Table "7" shows the scoring points of different cheese treatment during 6 months of ripening. For all cheese as ripening period progressed the scoring points markedly increased. The highest scoring points were for cheese made of silage milk. Gowing back to (table 7), ripening indices of 
Nassib, T. A. et al.

silage milk were higher than those of control cheese. The effect of silage feeding had more pronounced effect on flavour than on body and texture. In general, raw milk cheeses gained higher scoring points than heat treated milk cheeses. Many authors pointed out that raw milk cheese characterized with better flavour than pasteurized milk cheese. Hofi. et al. (1970) found that raw milk cheese scored higher than pasteurized milk cheese of flavour quality (52 out of 60 points Vs. 33), but shlightly lower on body and texture (28 out of 40 points, Vs. 33). Ayad (2002), Awad (2006) found that sensory data revealed that raw cheese received the highest flavour and texture score and the two pasteurized cheeses were different in taste. The lowest scoring points were for potassium sorbate cheese. It is well known that potassium sorbate could destroy many groups of microorganisms which may be responsible for ripening. Kinga, and Pirkov (1974) found that the composition of milk from cow's fed on silage was normal and hard cheese produced from it was given the highest grade.

Table (7): Effect of silage feeding, heat treatment and potassium sorbate addition on sensory evaluation of Ras cheese.

\begin{tabular}{|c|c|c|c|c|c|c|}
\hline \multicolumn{2}{|c|}{ Treatments } & $\begin{array}{l}\text { Ripening } \\
\text { period } \\
\text { (month) }\end{array}$ & $\begin{array}{c}\text { Color } \\
\text { appearance (15) }\end{array}$ & Body text (35) & Flavour (50) & Total (100) \\
\hline \multirow{14}{*}{ 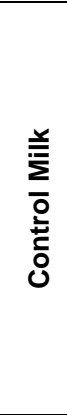 } & \multirow{7}{*}{ A } & 0 & 13 & 22 & 28 & 63 \\
\hline & & 1 & 13 & 24 & 30 & 67 \\
\hline & & 2 & 11 & 25 & 33 & 69 \\
\hline & & 3 & 10 & 27 & 35 & 72 \\
\hline & & 4 & 9 & 28 & 38 & 75 \\
\hline & & 5 & 9 & 30 & 41 & 80 \\
\hline & & 6 & 9 & 32 & 45 & 86 \\
\hline & \multirow{7}{*}{ B } & 0 & 12 & 19 & 25 & 56 \\
\hline & & 1 & 10 & 21 & 28 & 59 \\
\hline & & 2 & 9 & 22 & 29 & 60 \\
\hline & & 3 & 9 & 24 & 33 & 66 \\
\hline & & 4 & 8 & 25 & 35 & 68 \\
\hline & & 5 & 7 & 27 & 38 & 72 \\
\hline & & 6 & 8 & 29 & 42 & 79 \\
\hline \multirow{21}{*}{ 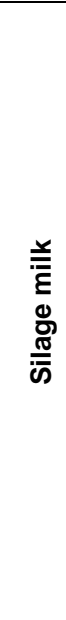 } & \multirow{7}{*}{ C } & 0 & 13 & 23 & 30 & 66 \\
\hline & & 1 & 12 & 24 & 32 & 68 \\
\hline & & 2 & 12 & 26 & 35 & 73 \\
\hline & & 3 & 11 & 28 & 37 & 76 \\
\hline & & 4 & 10 & 29 & 39 & 78 \\
\hline & & 5 & 9 & 31 & 44 & 84 \\
\hline & & 6 & 9 & 23 & 46 & 87 \\
\hline & \multirow{7}{*}{ D } & 0 & 12 & 19 & 27 & 58 \\
\hline & & 1 & 11 & 20 & 29 & 60 \\
\hline & & 2 & 10 & 22 & 32 & 64 \\
\hline & & 3 & 10 & 23 & 35 & 68 \\
\hline & & 4 & 9 & 27 & 37 & 73 \\
\hline & & 5 & 9 & 27 & 39 & 75 \\
\hline & & 6 & 8 & 31 & 42 & 81 \\
\hline & \multirow{7}{*}{$\mathbf{E}$} & 0 & 12 & 19 & 24 & 55 \\
\hline & & 1 & 12 & 22 & 26 & 60 \\
\hline & & 2 & 11 & 22 & 27 & 60 \\
\hline & & 3 & 10 & 24 & 29 & 63 \\
\hline & & 4 & 10 & 26 & 33 & 69 \\
\hline & & 5 & 9 & 28 & 36 & 73 \\
\hline & & 6 & 8 & 29 & 36 & 73 \\
\hline
\end{tabular}

A: Control milk (raw)

C: Raw silage milk

E: Heat treated silage milk $+0.5 \%$ Potassium sorbate
B: Control milk (Heat treated)
D: Heat treated silage milk 


\section{REFRENCES}

Abdou, S. M.; Abd El-Hamid, L. B.; Dawood, A.H.M.; Yousef, A.M; Mahran, G.A. (1977); "Studies on "Cephalotyre" Ras cheese coating. It effect on ripening" Egyptian journal of Dairy science. 5,(2): 91-200.

AOAC. (2000): Association Official Analytical Chemists. Official methods of Analysis, $17^{\text {th }}$ Ed Washington, Dc, U.S.A., Antoniour, K.D; Petridis, R; Raphaelides, S; Benormal, Z; and Resteloot. (2000). Text. J. Food. Sci. 65: 168-172.

Awad. S. (2006): "Texture and Flavour developmet in Ras cheese made from raw and pasteurized milk", Food Chemistry. 97, (3):394-400.

Ayad, E.H.E. (2004): "Flavour formation of Egyptian Ras cheese made from raw and pasteurized milk" $9^{\text {th }}$ Egyptian conference for dairy science and technology" International Agriculture Center, Cairo-Egypt, 9-11 October 209-532.

Difco Mannal (1971): "Dehydrated culture media and Reagent for microbiological", clinical laboratory producer.

El-Sheikh, M; Ducruet, P. and Maubois, J.L. (1994): "Manufacture of Ras cheese from fresh and recombined milks", Laboratories de Researches de Technologie Laitiere, INRA, 65, rue due saint, Brieuc, 35042, Rennescedex, France 74,297-305.

Gudkov, A. V. (1994): "Increasing the yield of cheeses and improving their quality", Molochnaya Promyshlennost, 2,6-8.

Gibbs, B. M. and Freame, B. F. (1965): "Methods for the recovery of clostridium from food", J. Apple, Bacterial, 28-95.

Hagrass, A; Sultan, N. G. and Hammad (1984): "Chemical properties of Ras cheese during ripening as affected by the addition of inactive dry yeast autolyzate", Egyptian, J. Dairy sci. 12:231-241.

Hofi, A.A. ; Yousef, E. H: Ghoneim, M.A. and Tawab, G. A.(1970): "Ripening changes in cephalotyre "Ras" cheese manufacture from raw and pasteurized milk with special reference to flavour", J. Dairy sci., $53,(9): 1207-121$

Ismail, M. M. (2001): "Manufacture of hard cheese using different type of milk Ph. D. Thesis. Faco. \& Agric. Mansoura Univ. Egypt.

Kosikowski, F. V. (1978): "Cheese and fermented milk food $3^{\text {rd }}$, published by the author", cournall. Univ. Ithaca, New Yourk, U.S.A.

Kinga. M. I and Pirkov, V. N. (1974): "Silage from maize grown on fertilized soil and processing quality of milk", Daklady - Vesoyoznoi - Ordena Lenina - Akademii - Sel - Skohozyaistvennykh - Nauk - imeni - V - I - Lenina, (7):24-25-46.

Ling, E.R (1963); A Text. Book of Dairy chemistry vol.2, practical $3^{\text {rd }}$ ed., champan and Hall, London, England.

Luck, E., (1972). 'Sorbin saure chemi- Biochemic mikrobiologie Technologie Vol.2, Hamburg B, Behr's Verlag p.42-87.

Omar, M.M. and Buchheim (1983), "Protein breakdown in Gouda type cheese made from recombined milk", Egyptian. J., Dairy sci., 11-281. 
Nassib, T. A. et al.

Pirisi, A., Piredda, G., Scintu, M.F and Fois, N. (2001); "Effect of feeding diets on quality characteristics of milk and cheese produced from Sorda dairy ewes", options mediterraneennes, serie A., seminaries mediterraneens 46: 115-119.

Rehm, H. J. (1961), Grenzhemmkon sentration - en- eler zugelassenen konservierungsmttel gegen micro organisms - Lebensin unters Forsch115,293-309.

Richardson, G.H., (1985) Standard methods of the Examination of Dairy products $15 \mathrm{~cd}$ American public Health Association, Washington. D. C.

Scott, R (1981), Cheese making practice, Applied sci. publishers LTD., N. Y. p.p.361-383.

Sakr, H.S.A (1998), Utilization of goat's milk in salt cheese manufacture msc, Thesis Fac., Agric., Zagazig Univ. Egypt.

Twab, G.A (1963); "The manufacture of Ras cheese", Dairy Dept., ministry of Agric. Cairo. UAR Unpublished.

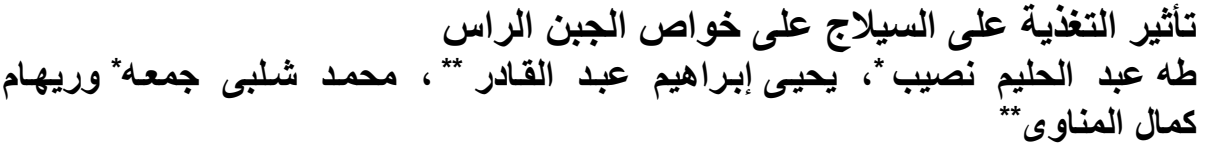

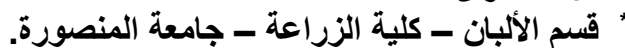

$$
\begin{aligned}
& \text { ” * معهد بحوث الإنتاج الحيوانى ـ الدقى - القاهرة. }
\end{aligned}
$$

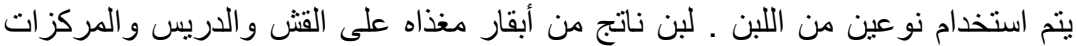

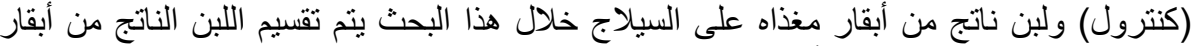

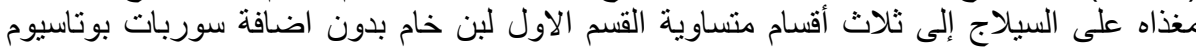

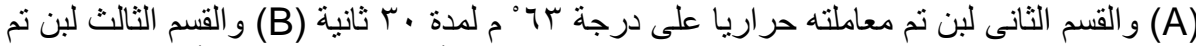

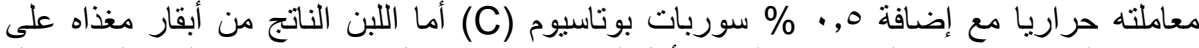

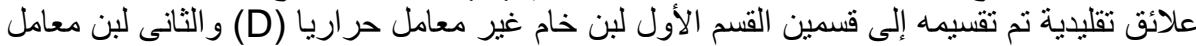

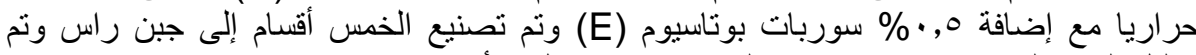

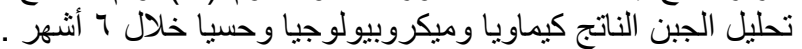

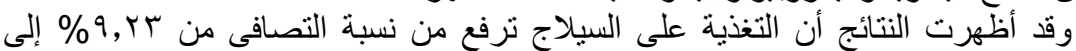

$$
\begin{aligned}
& \text { 11, 1 \% كما أنه وجد أن اللبن المعامل حراريا أعطى نتائج أعلى لنسبة التصافى عن الغير معامل }
\end{aligned}
$$

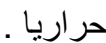

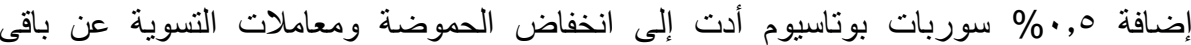

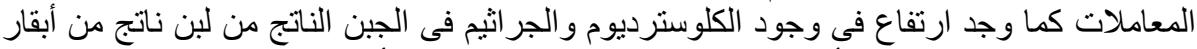

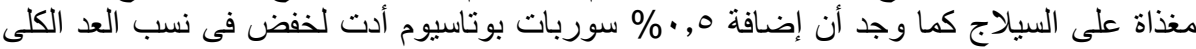

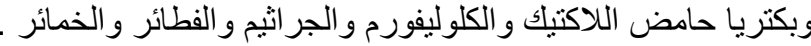

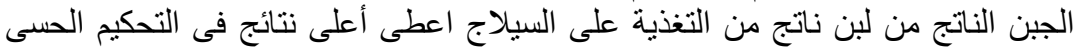

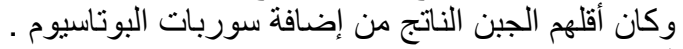

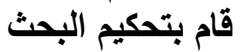

$$
\begin{aligned}
& \text { كلية الزراعة - جامعة المنصورة } \\
& \text { كلية الزراعة - جامعة القاهرة المنامة }
\end{aligned}
$$

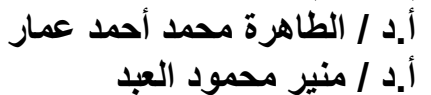

